\title{
Prevention Study
}

National Cancer Institute

\section{Source}

National Cancer Institute. Prevention Study. NCI Thesaurus. Code C49657.

A type of study protocol designed to evaluate intervention(s) for disease prevention. 